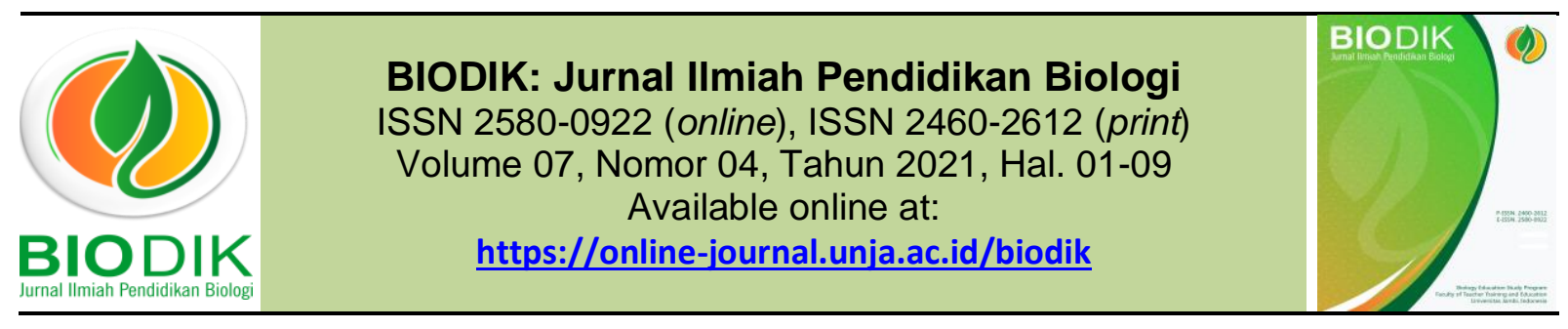

Research Article

\title{
Pengaruh Concept Attainment Terhadap Hasil Belajar IPA
}

\section{(The Effect Of Concept Attainment On IPA Learning Outcomes)}

\author{
Widiya Septian Dewi*, Sri Wardhani, Rusdy A Siroj \\ Prodi Pendidikan Biologi Program Pascasarjana \\ Fakultas Keguruan dan IImu Pendidikan Universitas Muhammadiyah Palembang \\ JI. Jenderal Ahmad Yani, Dua, 13 Ulu, Kec. Seberang Ulu II, Kota Palembang, Sumatera Selatan 30263 \\ ${ }^{*}$ Corresponding Author: widiyasdewi@gmail.com/s wardhaniump@yahoo.com
}

\begin{tabular}{|c|c|}
\hline Informasi Artikel & ABSTRACT \\
\hline $\begin{array}{l}\text { Submit: } 29-08-2021 \\
\text { Diterima: } 12-11-2021 \\
\text { Dipublikasikan: } 01-12-2021\end{array}$ & $\begin{array}{l}\text { This research is motivated by several statements which state that CAM can have } \\
\text { a positive effect on learning outcomes. The purpose of the study was to } \\
\text { determine whether there was a difference in the effect of applying the concept } \\
\text { attainment model on student learning outcomes in science subjects on the } \\
\text { structure and function of plant tissue when compared to the lecture method for } \\
\text { class VIII SMP Negeri in Kisam Tinggi District, OKU Selatan Regency. The } \\
\text { research method used is an experimental design with a quasi-experimental } \\
\text { design type Nonequeivalent control group design. The population of this study } \\
\text { were all eighth grade students of SMP Negeri in Kisam Tinggi District which } \\
\text { consisted of } 2 \text { schools. The sample at SMP } 1 \text { Kisam Tinggi for the experimental } \\
\text { class is VIII E while the control class is VIII B. The sample used at SMP } 2 \text { Kisam } \\
\text { Tinggi for the experimental class is VIII B while the control class is VIII A. The } \\
\text { sampling technique used was purposive sampling. Collecting data with a written } \\
\text { test that is by giving a pretest and posttest. The results of the study the average } \\
\text { posttest value of the experimental class was } 76.00 \text { and the average posttest } \\
\text { value of the control class was } 51.45 \text {. Data analysis was carried out using the } \\
\text { Independent Sample T Test with the help of the SPSS } 23.0 \text { program. Obtained } \\
\text { a significance value of } 0.000 \text {. The value of sig < } 0.005 \text { indicates that Ho is } \\
\text { rejected, meaning that there is a difference in the effect of the application of the } \\
\text { concept attainment model on the learning outcomes of plant tissue structure and } \\
\text { function when compared to the lecture method for class VIII of public junior high } \\
\text { schools in Kisam Tinggi sub-district, OKU Selatan district }\end{array}$ \\
\hline & Key words: CAM Learning Outcomes; Concept Understanding \\
\hline Penerbit & ABSTRAK \\
\hline $\begin{array}{l}\text { Program Studi Pendidikan Biologi } \\
\text { FKIP Universitas Jambi, } \\
\text { Jambi- Indonesia }\end{array}$ & $\begin{array}{l}\text { Penelitian ini dilatar belakangi oleh beberapa pernyataan yang menyatakan CAM } \\
\text { dapat berpengaruh positif terhadap hasil belajar. Tujuan penelitian untuk } \\
\text { mengetahui apakah ada perbedaan pengaruh penerapan concept attainment } \\
\text { model terhadap hasil belajar siswa mata pelajaran IPA materi struktur dan fungsi } \\
\text { jaringan tumbuhan jika dibandingkan dengan metode ceramah kelas VIII SMP } \\
\text { Negeri se-Kecamatan Kisam Tinggi Kabupaten OKU Selatan. Metode penelitian } \\
\text { yang digunakan adalah eksperimen dengan rancangan quasi experimental } \\
\text { design tipe Nonequeivalent control group design. Populasi penelitian ini seluruh } \\
\text { siswa kelas VIII SMP Negeri se-Kecamatan Kisam Tinggi yang terdiri dari } 2 \\
\text { sekolah. Sampel pada SMP } 1 \text { Kisam Tinggi untuk kelas eksperimen yaitu VIII E } \\
\text { sedangkan kelas kontrol VIII B, Sampel yang digunakan pada SMP } 2 \text { Kisam } \\
\text { Tinggi untuk kelas eksperimen yaitu VIII B sedangkan kelas kontrol VIII A. Teknik } \\
\text { pengambilan sampel mengunakan purposive sampling. Pengumpulan data }\end{array}$ \\
\hline
\end{tabular}


dengan test tertulis yaitu dengan cara memberikan pretest dan Posttest. Hasil penelitian nilai rata-rata posttest kelas eksperimen 76,00 dan nilai rata-rata posttest kelas kontrol 51,45 Analisis data dengan Independent Sample T Test dengan bantuan program SPSS 23.0. Diperoleh nilai signifikansi sebesar 0,000 . Nilai sig $<0,005$ hal ini menunjukkan bahwa $\mathrm{H}_{0}$ ditolak artinya terdapat perbedaan pengaruh penerapan concept attainment model terhadap hasil belajar materi struktur dan fungsi jaringan tumbuhan jika dibandingkan dengan metode ceramah kelas VIII SMP Negeri se-Kecamatan Kisam Tinggi Kabupaten OKU Selatan

Kata kunci: CAM, Hasil Belajar, Pemahaman Konsep

This BIODIK : Jurnal IImiah Pendidikan Biologi is licensed under a CC BY-NC-SA (Creative Commons Attribution-ShareAlike 4.0 International License)

\section{PENDAHULUAN}

Pendidikan merupakan rangkaian peristiwa yang kompleks dan usaha yang dijalankan dengan sadar, sengaja, teratur, terencana dengan tujuan untuk mengubah tingkah laku manusia kearah yang diinginkan. Pendidikan merupakan kunci untuk semua kemajuan dan perkembangan yang berkualitas karena pendidikan merupakan proses perubahan tingkah laku siswa menjadi manusia dewasa yang mampu hidup mandiri dan sebagai anggota masyarakat dalam lingkungan alam sekitar(Anggraini, 2018).

"Pendidikan adalah bagian dari seluruh kegiatan yang dilakukan oleh masyarakat yang berbangsa dan bernegara. Oleh sebab itu pendidikan menjadi salah satu faktor cita cita bangsa dengan demikian kegiatan pendidikan harus dikelola dan diorganisasikan sebaik mungkin karena dengan hal demikian diharapkan pendidikan dapat menjadi sarana untuk mewujudkan cita-cita nasional. Nasionalisme sendiri dapat kita artikan sebagai kegiatan besar yang dilakukan dalam upaya menggerakan dan mengawasi kegiatan masyarakat Indonesia. Pendidikan merupakan sarana yang dapat kita lakukan untuk mendapakan pengetahuan yang lebih baik"(Agustin I. N. N. \& Supriyono A, 2009).

"Permasalahan pendidikan di Indonesia sama seperti mengurai benang kusut, sulit menemukan ujung pangkal permasalahannya. Proses pendidikan yang dijalani selama hampir 76 tahun kemerdekaan Republik Indonesia tidak membuat perubahan yang signifikan terhadap pola pikir sumberdaya manusia. Tingkat pendidikan negara yang secara sumberdaya alam sangat kaya raya ini tertinggal jauh di bawah negara tetangga. Salah satu solusi pada permasalahan ini yaitu harus ada agent of change yang peduli terhadap nasib bangsa, sehingga dengan kepeduliannya tersebut dapat mengubah wajah pendidikan Indonesia menjadi lebih baik"(Priarti, 2012).

Pendidikan di Indonesia pada saat ini, masih belum menunjukkan peningkatan yang secara signifikan salah satunya dalam ilmu sains. Hal ini dapat dilihat dari hasil penelitian tentang penilaian motivasi belajar level internasional yang dilakukan oleh Organization for Economic Co-operationand Development (OECD) melalui Programme for International Student Assessment (PISA) pada tahun 2018 menetapkan "Indonesia berada pada urutan ke 70 dari 78 negara peserta. Selama hampir 20 tahun terakhir sejak PISA merilis hasil kemampuan literasi sains peserta didik di seluruh dunia, Negara Indonesia selalu berada pada urutan bawah. Hal ini menunjukan bahwa kualitas pembelajaran di Indonesia jauh di bawah negara-negara anggota OECD" (Fuadi et al., 2020).

Rendahnya kualitas pembelajaran di Indonesia dapat dilihat dari hasil belajar siswa salah satunya tercermin dari rendahnya nilai rata-rata Ujian Nasional (UN). Berdasarkan data dari program aplikasi Pamer UN tahun 20172019. Nilai rata-rata Ujian Nasional (UN) khusus untuk mata pelajaran IPA Pada Pulau Sumatera yaitu 43,65. Salah satu Provinsi di Pulau Sumatera yang mendapat nilai terendah yaitu Provinsi Sumatera Selatan. Provinsi Sumatera Selatan mempunyai 17 kabupaten/kota. Nilai rata-rata UN mata pelajaran IPA tertinggi terdapat di SMP Kabupaten 
Lubuk Linggau dan yang terendah terdapat di SMP kabupaten OKU Selatan. Kabupaten OKU Selatan memiliki 19 Kecamatan. Nilai rata-rata UN mata pelajaran IPA tertinggi terdapat di SMP Kecamatan Sindang Danau dan nilai ratarata terendah terdapat di SMP Kecamatan Kisam Tinggi.

Berdasarkan data dari program aplikasi Pamer UN tahun 2017-2019. Pada SMP Negeri se-Kecamatan Kisam Tinggi untuk nilai rata-rata UN mata pelajaran IPA, materi pembelajaran yang mendapatkan nilai rata-rata terendah yaitu pada materi struktur dan fungsi jaringan makhluk hidup (Tumbuhan dan Hewan). Hasil analisis nilai rata-rata UN pada materi struktur dan fungsi jaringan mahluk hidup nilai terendah terdapat pada sub bab materi struktur dan fungsi jaringan tumbuhan

Struktur dan fungsi jaringan tumbuhan mempelajari susunan dan bentuk berbagai jaringan pada tumbuhan yang bersifat mikroskopis. Materi ini tergolong cukup sulit dipahami siswa karena bersifat mikroskopis tidak dapat dilihat dalam proses nyata (abstrak) dan tidak familiar dikehidupan sehari-hari. "Materi struktur dan fungsi jaringan tumbuhan sulit dipahami disebabkan karena siswa tidak dapat melihat langsung dengan indera, memerlukan bantuan mikroskop yang tersedia di sekolah untuk melihatnya. Guru dapat merancang sumber belajar biologi sebagai bentuk inovasi pembelajaran berbasis pemikiran kritis, kreatif, inovatif untuk meningkatkan efektivitas pembelajaran"(Gusti \& Syamsurizal, 2021).

Pada SMP Negeri se-Kecamatan Kisam Tinggi berdasarkan hasil obeservasi awal yang dilakukan sebelum pandemi Covid-19 dimana proses pembelajaran masih dilakukan secara tatap muka peneliti menemukan beberapa fakta yaitu 1). Pembelajaran di kelas disajikan dengan minimnya keterlibatan siswa, 2). Guru tidak menggunakan media apapun pada saat proses pembelajaran, 3). Guru tidak menggunakan model pembelajaran pada saat mengajar, 4). Siswa hanya duduk, mendengar dan mencatat apa yang disampaikan guru, 5). Sebagian besar siswa tidak memberi respon terhadap guru ketika diberi pertanyaan secara lisan. 6). Informasi tentang konsep-konsep IPA hanya didapat melalui penjelasan dari guru dan buku cetak saja, 7). Pada proses pembelajaran siswa hanya sedikit sekali diberi kesempatan untuk terlibat aktif secara langsung dalam mengembangkan pengetahuannya menjadi sebuah pemahaman. 8). Pembelajaran masih diarahkan pada menghafal konsep-konsep IPA, siswa hanya menghafal konsep bukan memahami konsep yang diajarkan.

Berdasarkan penjelasan diatas maka "guru harus cermat dalam memilih model pembelajaran dan merancang program serta strategi pembelajaran, sehingga pembelajaran yang dilakukan menjadi pembelajaran yang menarik, aktual, dan fungsional bagi siswa. Pemilihan model pembelajaran oleh guru mempunyai dampak yang sangat esensial bagi hasil belajar siswa". Model pembelajaran yang dapat digunakan salah satunya yaitu concept attainment model. Pada model pembelajaran concept attainmet kegiatan belajar tidak hanya teacher center tetapi siswa terlibat aktif dalam proses pembelajaran, siswa aktif dalam mencari konsep-konsep pembelajaran serta aktif dalam komunikasi dan juga terlibat langsung dalam proses pembelajaran (Irmayani, 2019).

"Concept attainment adalah model pembelajaran yang dirancang untuk menata atau menyusun data sehingga konsep-konsep penting dapat dipelajari secara tepat dan efisien. Model ini memiliki pandangan bahwa para siswa tidak hanya dituntut untuk mampu membentuk konsep melalui proses pengklasifikasian data akan tetapi mereka juga harus dapat membentuk susunan konsep dengan kemampuannya sendiri selain itu juga lebih menekankan kepada siswa untuk menemukan suatu konsep dengan cara analisis terhadap contoh yang diberikan oleh guru yang berhubungan dengan konsep yang sedang dipelajari"(Istuningsih, 2016).

"Menurut Joyce Bruce (2009) dalam Putri (2017), sintak Concept attainment model terdapat tiga tahapan. Tahap pertama presentasi data dan identifikasi konsep meliputi guru menyajikan contoh-contoh yang telah dilabeli, siswa membandingkan ciri-ciri positif dan negatif dari contoh yang dikemukakan, siswa 
menyimpulkan dan menguji hipotesis, siswa memberikan arti sesuai dengan ciri-ciri esensial. Tahap kedua menguji pencapaian konsep yang meliputi siswa mengidentifikasi tambahan contoh yang tidak dilabeli, guru mengkonfirmasikan hipotesis, konsep nama dan defenisi sesuai dengan ciri-ciri esensial, siswa membuat contoh-contoh. Tahapan ketiga menganalisa kemampuan berfikir strategis yang meliputi: siswa mendeskripsikan pemikiran-pemikiran mereka, siswa mendiskusikan hipotesis dan atribut-atribut, siswa mendiskusikan bentuk dan jumlah hipotesis Kelebihan"(Putri, 2017).

"Kelebihan Concept Attainment Model yaitu (1). Guru langsung memberikan presentasi informasi-informasi yang akan memberikan ilustrasi-ilustrasi tentang topik yang kan diajari oleh siswa, sehingga siswa mempunyai parameter dalam pencapaian tujuan pembelajaran (2). Melatih konsep siswa, menghubungkan pada kerangka yang ada, dan menghasilkan pemahaman materi yang lebih mendalam (3). Concept Attainment meningkatkan pemahaman konsep siswa"(Putri, 2017).

Berdasarkan latar belakang masalah di atas maka tujuan penelitian yang menjadi pokok penelitian ini yaitu untuk mengetahui apakah terdapat pengaruh penerapan Concept Attainment Model terhadap hasil belajar mata pelajaran IPA kelas VIII SMP Negeri se-Kecamatan Kisam Tinggi Kabupaten OKU Selatan. Agar masalah dapat diteliti secara spesifik, maka penelitian ini dibatasi pada beberapa ruang lingkup permasalahan yaitu hasil belajar yang diukur hanya pada ranah kognitif saja dan pada indkator pemahaman konsep. Selain itu penelitian ini hanya pada materi struktur dan fungsi jaringan tumbuhan

\section{METODE PENELITIAN}

Penelitian dilaksanakan di SMP Negeri se-Kecamatan Kisam Tinggi Kabupaten OKU Selatan yang terdiri dari 2 sekolah yaitu SMP Negeri 1 Kisam Tinggi dan SMP Negeri 2 Kisam Tinggi pada tanggal 29 Maret 2021 sampai tanggal 30 April 2021. Penelitian ini merupakan quasi experimental design dengan bentuk nonequivalent control group design. Populasi adalah seluruh siswa kelas VIII SMP negeri seKecamatan Kisam Tinggi yang terdiri dari 2 sekolah. Sampel diambil dengan nonprobability sampling dengan aturan purposive sampling. Sampel pada penelitian ini SMP negeri 1 Kisam Tinggi kelas eksperimen yaitu kelas VIIIE dan kelas kontrol VIIIB sedangkan pada SMP negeri 2 Kisam Tinggi kelas eksperimen yaitu kelas VIIIB dan kelas kontrol VIIIA. Teknik pengumpulan data dengan tes tertulis yaitu dengan cara memberikan pretest dan posttest. Uji hipotesis pada penelitian ini dilakukan dengan analisis Independent Sample T Test berbantuan program SPSS 23.0

\section{HASIL PENELITIAN DAN PEMBAHASAN}

Hasil

Hasil pretest yang diberikan sebelum dilakukan proses pembelajaran pada siswa kelas eksperimen dan kontrol yang dilaksanakan di SMP Negeri se-kecamatan Kisam Tinggi untuk mata pelajaran IPA dapat dilihat pada tabel 1.

Tabel 1 Nilai Rata-Rata Pretest Kelas Eksperimen dan Kelas Kontrol

\begin{tabular}{ccccc}
\hline Kelas & Jumlah Siswa & Nilai Minimum & Nilai Maksimum & Nilai Rata-rata \\
\hline Eksperimen & 55 & 15 & 60 & 33,27 \\
\hline Kontrol & 55 & 20 & 55 & 33,74 \\
\hline
\end{tabular}

Berikut ini nilai rata-rata hasil posttest, posttest diberikan kepada siswa kelas eksperimen dan kontrol setelah dilaksanakan proses pembelajaran materi struktur dan fungsi jaringan tumbuhan. Adapun 
materi struktur dan fungsi jaringan tumbuhan ini terdapat 4 kali pertemuan, posttest diberikan setelah proses pembelajaran pertemuan keempat selesai atau berakhir. Nilai rata-rata posttest dapat dilihat pada tabel 2.

Tabel 2 Nilai Rata-Rata Posttest Kelas Eksperimen dan Kelas Kontrol

\begin{tabular}{ccccc}
\hline Kelas & Jumlah Siswa & Nilai Minimum & Nilai Maksimum & Nilai Rata-rata \\
\hline Eksperimen & 55 & 55 & 90 & 76,00 \\
\hline Kontrol & 55 & 40 & 70 & 51,45 \\
\hline
\end{tabular}

Uji hipotesis pada penelitian ini dilakukan dengan bantuan program SPSS 23.0 dengan analisis Independent Sample T Test. Hasil uji hipotesis dapat dilihat pada tabel 3.

Tabel 3. Hasil uji hipotesis dengan analisis Independent Sample T Test.

\begin{tabular}{cc}
\hline Statistik & Nilai Signifikan \\
\hline Sig(2-tailed $)$ & 0.000 \\
\hline Tingkat Sig $(\mathrm{a})$ & 0.005 \\
\hline
\end{tabular}

Hasil dari uji hipotesis dengan analisis Independent Sample T Test diperoleh nilai Sig(2-tailed) $0.000<0,005$ dapat disimpulkan $\mathrm{H}_{0}$ ditolak, hal ini berarti terdapat perbedaan pengaruh penerapan concept attainment model terhadap hasil belajar siswa materi struktur dan fungsi tumbuhan jika dibandingkan dengan metode ceramah kelas VIII SMP Negeri se-Kecamatan Kisam Tinggi Kabupaten OKU Selatan.

Nilai yang digunakan untuk uji hipotesis pada penelitian ini hanya menggunakan nilai posstest saja dikarenakan dari hasil uji beda nilai rata-rata pretest kelas eksperimen dan kelas kontrol memiliki nilai rata-rata yang sama dan tidak memiliki perbedaan yang signifikan. Hal ini dapat diihat pada tabel 4.

Tabel 4. Hasil uji beda nilai rata-rata pretest Independen Samples Test

\begin{tabular}{ccccccc}
\hline & & \multicolumn{2}{c}{$\begin{array}{c}\text {-evene's Test for Equality of } \\
\text { Variances }\end{array}$} & \multicolumn{2}{c}{ t-test for Equality of Means } \\
\cline { 3 - 7 } & & $\mathrm{F}$ & $\mathrm{Sig}$ & $\mathrm{T}$ & $\mathrm{df}$ & jig. (2-tailed) \\
\hline \multirow{2}{*}{ Pretest } & $\begin{array}{c}\text { jual variances } \\
\text { assumed }\end{array}$ & 4.411 & 0,38 & -0.213 & 108 & 0.832 \\
\hline $\begin{array}{c}\text { jual variances not } \\
\text { assumed }\end{array}$ & & & -0.213 & 103.559 & 0.832 \\
\hline
\end{tabular}

Berdasarkan tabel 4 di atas dapat diketahui nilai Sig. (2-tailed) yaitu 0,832 >0,005 hal ini berarti tidak ada perbedaan yang signifikan nilai rata-rata pretest antara kelas eksperimen dan kelas kontrol. Hasil uji beda nilai rata-rata posttest pada kelas eksperimen dan kelas kontrol dapat dilihat pada tabel 5 . 
BIODIK: Jurnal IImiah Pendidikan Biologi

Vol. 07, No. 04 (2021), Hal. $01-09$

Tabel 5. Hasil uji beda nilai rata-rata posttest Independen Samples Test

\begin{tabular}{|c|c|c|c|c|c|c|}
\hline & & \multicolumn{2}{|c|}{$\begin{array}{c}\text { evene's Test for Equality of } \\
\text { Variances }\end{array}$} & \multicolumn{3}{|c|}{ t-test for Equality of Means } \\
\hline & & $\mathrm{F}$ & Sig. & $\mathrm{t}$ & $\mathrm{df}$ & jig. (2-tailed) \\
\hline Posttest & $\begin{array}{l}\text { Jual variances } \\
\text { assumed }\end{array}$ & .554 & .458 & 14.464 & 108 & .000 \\
\hline & $\begin{array}{l}\text { |ual variances not } \\
\text { assumed }\end{array}$ & & & 14.464 & 107,748 & .000 \\
\hline
\end{tabular}

Berdasarkan tabel 5 di atas dapat diketahui nilai Sig. (2-tailed) yaitu 0,000<0,005 hal ini berarti terdapat perbedaan yang signifikan nilai rata-rata posttest antara kelas eksperimen dan kelas kontrol.

Concept attainment model berpengaruh positif terhadap hasil belajar siswa, hal ini dapat kita ketahui dari Hasil uji hipotesis yang diperoleh nilai $\mathrm{Sig}$ (2-tailed) $0.000<0,005$ berarti $\mathrm{H}_{0}$ ditolak. Artinya terdapat perbedaan pengaruh penerapan concept attainment model terhadap hasil belajar siswa materi struktur dan fungsi tumbuhan jika dibandingkan dengan metode ceramah kelas VIII SMP Negeri se-Kecamatan Kisam Tinggi Kabupaten OKU Selatan. Hal ini juga dapat dilihat dari nilai rata-rata posttest kelas eksperimen dengan menggunakan concept attainment model lebih tinggi daripada nilai rata-rata posttest kelas kontrol dengan menggunakan metode ceramah. Perbedaan hasil posttest kelas eksperimen dan kelas kontrol dikarenakan pada kelas eksperimen proses pembelajaran menggunakan concept attainment model. Concept attainment model adalah model pembelajaran yang dirancang untuk menata atau menyusun data sehingga konsep-konsep penting dapat dipelajari secara tepat dan efisien.

Penerapan concept attainment model dapat meningkatkan hasil belajar siswa karena pada concept attainment model ini siswa akan mencari informasi tambahan berkaitan dengan materi pembelajaran, melalui soal,contoh-contoh yang berkaitan dengan materi pembelajaran dan penjelasan yang disampaikan oleh guru. Oleh sebab itu materi akan lebih mudah diingat dan dipahami oleh siswa, sehingga kemampuan kognitif siswa dapat meningkat. "Menurut Mayer (2012) dalam Nazar Muhammad \& Djufri (2014), menyebutkan bahwa implementasi model concept attainment dapat memberikan hasil yang maksimal bagi siswa dalam mempelajari konsep baru, serta menuntun siswa merekonstruksi proses pembelajaran menggunakan contoh-contoh lalu menarik kesimpulan sehingga dihasilkan sebuah konsep baru"(Nazar Muhammad, Djufri, 2014).

Meningkatnya hasil belajar pada kelas eksperimen yang proses pembelajaran menggunakan concept attainment model (CAM) dikarenakan pada CAM mempunyai beberapa tahapan pembelajaran yang membantu siswa dalam melatih kemampuan komunikasi dan berpikir kritis serta memahami konsep-konsep pada materi pembelajaran. Adapun tahapan-tahapan concept attainment model yaitu "tahapan pembelajaran pertama meliputi penyajian data dan identifikasi konsep, pada tahap ini siswa diminta membandingkan ciri-ciri dalam contoh dan non contoh, Tahapan kedua yaitu tahapan pengetesan pencapaian konsep, pada tahap ini siswa diminta mengidentifikasi contoh-contoh konsep dan membuat contoh tambahan. Tahap ketiga yaitu tahap analisis strategi berpikir, pada tahap ini siswa terlatih untuk mengkomunikasikan materi pembelajaran". Pada proses pembelajaran dengan concept attainment model siswa diminta untuk mengungkapkan konsep dengan kata-kata sendiri, mengungkapkan alasanalasan yang berkaitan dengan hipotesis, membuat contoh tambahan, menuliskan hasil pengamatan yang ditemukan, serta membuat kesimpulan dari hipotesis serta hasil temuan pada proses pembelajaran, sehingga dengan model pembelajaran concept attainment ini secara teoritis diyakini dapat mempermudah siswa memahami materi pembelajaran dan berdampak positif dengan hasil belajar 
(Anggraini, 2018).

Concept attainment model dapat berpengaruh positif terhadap hasil belajar salah satunya juga dpengaruhi oleh kelebihan yang dimiliki oleh model pembelajaran ini. "Kelebihan model pembelajaran concept attainment adalah guru langsung memberikan presentasi informasi-informasi yang akan memberikan ilustrasiilustrasi tentang topik yang akan dipelajari oleh siswa, sehingga siswa mempunyai parameter dalam pencapaian tujuan pembelajaran, concept attainment melatih konsep siswa, menghubungkannya dengan konsep materi pelajaran yang akan dipelajari selanjutnya, sehingga menghasilkan pemahaman materi yang lebih mendalam terhadap pemahaman konsep siswa"(Putri, 2017).

"Menurut Ridwan (2013) dalam Sijabat (2019), Concept attainment memiliki kelebihan yang dapat memperbaiki masalah dalam pembelajaran. Dalam model ini siswa akan mempunyai gambaran umum tentang konsep materi pembelajaran, dengan demikian pembelajaran ini akan lebih aktif karena adanya pertanyaanpertanyaan siswa untuk memastikan apakah gambaran umum yang dimilikinya sesuai dengan konsep materi yang diajarkan. Siswa juga dapat mengukur kemampuannya dalam pencapaian konsep dengan mengoreksi hasil pemikirannya dengan konsep matematika yang ada. Kemungkinan alasan siswa untuk lupa akan konsep juga dapat diperkecil, karena pada model ini siswa bukan menghafal melainkan menemukan konsep dari hasil pemikirannya sendiri berdasarkan ide-ide yang diberikan guru. Selain kelebihan yang telah dijelaskan"(Sijabat et al., 2019).

Penelitian mengenai concept attainment model sebelumnya pernah dilakukan oleh beberapa peneliti. Risdawati (2020) menyatakan "hasil belajar siswa mata pelajaran Biologi setelah penerapan model pembelajaran pencapaian konsep (Concept Attainment) di kelas XI SMAN 11 Bulukumba menujukkan rata-rata tingkat pencapaian siswa setelah penerapan berada pada kategori tinggi". Hal ini menunjukkan concept attainment berpengaruh positif terhadap hasil belajar siswa terbukti dari setelah penerapan concept attainment tingkat pencapaian siswa berada pada kategori tinggi (Risadwati. Muh. Khalifah Mustami, 2020).

Hasil penelitian yang dilakukan oleh Yulilina \& Rusdi (2016) tentang "pengaruh concept attainment terhadap kemampuan komunikasi dan pemahaman konsep siswa pada materi sistem reproduksi menunjukkan bahwa terdapat pengaruh concept attainment terhadap kemampuan komunikasi dan pemahaman konsep siswa pada materi sistem reproduksi. Siswa yang menggunakan model pembelajaran concept attainment memiliki nilai lebih tinggi dibanding siswa yang menggunakan model pembelajaran STAD"(Yulilina. R, Rusdi, 2016).

Hasil Penelitian Marzuzi (2019) "menunjukkan bahwa pemahaman konsep siswa yang belajar materi Plantae melaui model concept attainment secara signifikan lebih tinggi daripada kelas kontrol Kemampuan pemahaman konsep siswa pada kelas eksperiman memperoleh nilai rata-rata hingga 85 diatas rata-rata KKM. Keaktifan siswa pada pembelajaran dengan model Concept Attainment juga lebih tinggi daripada kelas kontrol. Minat belajar siswa dengan model Concept Attainment menggunakan peta konsep memiliki skor tertinggi yaitu 78.38 dengan kategori tinggi sedangkan pada kelas kontrol 65.34 dengan kategori sedang"(Marzuzi. H, 2019).

"Concept Attainment Model merupakan sebuah model pengajaran yang dirancang untuk membantu siswa dalam mengembangkan dan menguatkan pemahaman siswa tentang konsep dan mempraktikkan berpikir kritis dalam pembelajarannya. concept attainment juga dapat memberi siswa pengalaman dengan metode ilmiah, terutama pengalaman dengan pengujian hipotesis, pengalaman yang kerap sulit diberikan di dalam bidang materi selain sains, dan dirancang secara unik untuk memberi siswa latihan membuat kesimpulan"(Ahmed et al., 2012).

"Concept Attainment Model bertujuan untuk membantu peserta didik memahami suatu konsep tertentu.Peserta didik yang telah mencapai konsep tidak hanya mampu menghapal sejumlah konsep yang telah dipelajarinya, tetapi ia mampu menerapkannya pada aspek lainnya dengan mengembangkan konsep berpikirnya. Pembelajaran dengan penerapan concept attainment model dapat menarik keingintahuan peserta didik terhadap contoh gambar dan noncontoh gambar. Menampilkan gambar yang menarik atau belum pernah dilihat peserta didik dapat membangkitkan ide peserta didik untuk 
diungkapkan pada saat itu dan memiliki daya serap serta daya ingat yang lebih kuat terhadap materi"(Agustina et al., 2016).

\section{SIMPULAN}

Berdasarkan hasil penelitian dan pembahasan maka dapat disimpulkan bahwa terdapat perbedaan pengaruh penerapan concept attainment model terhadap hasil belajar siswa materi struktur dan fungsi jaringan tumbuhan jika dibandingkan dengan metode ceramah kelas VIII SMP Negeri seKecamatan Kisam Tinggi Kabupaten OKU Selatan. Selatan. Hal ini dapat kita ketahui dari Hasil uji hipotesis yang diperoleh nilai Sig(2-tailed) $0.000<0,005$ artinya $\mathrm{H}_{0}$ ditolak, selain itu juga dapat dilihat dari nilai rata-rata posttest kelas eksperimen dengan menggunakan concept attainment model yaitu 76,00 sedangkan nilai rata-rata posttest kelas kontrol dengan menggunakan metode ceramah 51,45.

\section{UCAPAN TERIMA KASIH}

Dengan penuh rasa syukur atas kenikmatan yang diberikan Allah kepada kita semua. Penulis mengucapkan terimakasih kepada kepada orang tua yang selalu memberikan motivasi dan doa. Terima kasih kepada pembimbing 1 saya Dr. Sri Wardhani, M.Si dan pembimbing 2 saya Dr. Rusdy A Siroj, M.Pd yang sudah memberikan saran dalam membuat artikel ini, tidak lupa saya ucapkan banyak terimakasih kepada kepala sekolah SMP Negeri 1 Kisam Tinggi dan SMP Negeri 2 Kisam Tinggi Kabupaten OKU Selatan, yang sudah memberikan waktu dan kesempatan untuk penelitian ini.

\section{RUJUKAN}

Agustin I. N. N. \& Supriyono A. (2009). Permasalahan Pendidikan Di Indonesia. Magistra, Vol 21, No 69 (2009): Magistra Edisi Juni, 15. http://journal.unwidha.ac.id/index.php/magistra/article/view/186

Agustina, R., Huzaifah, S., \& Dayat, E. (2016). Pengaruh Penerapan Model Pencapaian Konsep (Concept Attainment Model) Terhadap Hasil Belajar Peserta Didik Pada Materi Jamur Kelas X Sma Negeri 2 Inderalaya Utara. Jurnal Pembelajaran Biologi: Kajian Biologi Dan Pembelajarannya, 3(2), 200-213. https://doi.org/10.36706/fpbio.v3i2.4684

Ahmed, I., Ahmed Gujjar, A., Ali Janjua, S., Bajwa, N., Mohanlal, S., Sharada, B. A., Fatihi, A. R., Gusain, L., Marie Bayer, J., Ravichandran, S. M., Baskaran, G., \& Ramamoorthy, L. (2012). LANGUAGE IN INDIA Strength for Today and Bright Hope for Tomorrow A Comparative Study of Effectiveness of Concept Attainment Model and Traditional Method in Teaching of English in Teacher Education Course. 12(March), 216-227. www.languageinindia.com

Anggraini, L. M. (2018). Pengaruh Model Pembelajaran Concept Attainment Berbasis Masalah Terhadap Pemahaman Konsep dan Minat Belajar Siswa Kelas XI SMA Negeri 8 Purworejo Tahun Pelajaran 2015/2016. JNPM (Jurnal Nasional Pendidikan Matematika), 2(2), 284. https://doi.org/10.33603/jnpm.v2i2.1473

Fuadi, H., Robbia, A. Z., Jamaluddin, J., \& Jufri, A. W. (2020). Analisis Faktor Penyebab Rendahnya Kemampuan Literasi Sains Peserta Didik. Jurnal IImiah Profesi Pendidikan, 5(2), 108-116. https://doi.org/10.29303/jipp.v5i2.122

Gusti, U. A., \& Syamsurizal, S. (2021). Analisis Urgensi Pengembangan Booklet Pada Materi Struktur Dan Fungsi Jaringan Tumbuhan Kelas Xi. Bjbe, 3(1), 59-66.

Irmayani. (2019). Upaya Meningkatkan Hasil Belajar IPS Model Pembelajaran Concept Attainment Pada Siswa Kelas VI.C SDN 09 Pasaman. 109-120.

Istuningsih, W. (2016). 'Efektivitas Model Pembelajaran Concept Attainment Dan Mind Mapping Terhadap Hasil Belajar Siswa Pada Mata Pelajaran Ekonomi Kelas Xi Ips Sma Negeri 2 Karanganyar Tahun Ajaran 2015/2016', 2016(2). 20. 
Marzuzi. H, R. . . (2019). Penguasaan Konsep Biologi, Keaktifan dan Minat Siswa pada Pembelajaran Biologi dengan Peta Konsep melalui Model Concept Attainment. Jurnal IImiah Pendidikan MIPA, 111.

Nazar Muhammad, Djufri, M. (2014). Penerapan Model Concept Attainment Terhadap Hasil Belajar Siswa Pada Materi Metabolisme. Jurnal Biologi Edukasi, 6(1), 9-15.

Priarti, M. (2012). Meretas Permasalahan Pendidikan di Indonesia. Jurnal IImiah Pendidikan MIPA, 2(3), $227-234$.

Putri, D. P. (2017). Model Pembelajaran Concept Attainment Dalam Meningkatkan Pemahaman Konsep Matematika. Jurnal Tatsqif, 15(1), 97-130. https://doi.org/10.20414/j-tatsqif.v15i1.1319

Risadwati. Muh. Khalifah Mustami. (2020). Pengaruh Model Pembelajaran Concept Attainment Terhadap Aktivitas dan Hasil Belajar Siswa Pada Mata Pelajaran Biologi Siswa kelas XI IPA SMAN 11 Bulukumba. 5(2), 158-177. http://repo.iain-tulungagung.ac.id/id/eprint/14700

Sijabat, F. T., Muchlis, E. E., \& Yensy, N. A. (2019). Penerapan Model Pembelajaran Concept Attainment Untuk Meningkatkan Aktivitas Matematika Siswa Smp. Jurnal Penelitian Pembelajaran Matematika Sekolah (JP2MS), 3(1), 13-20. https://doi.org/10.33369/jp2ms.3.1.13-20

Yulilina. R, Rusdi, A. (2016). Pengaruh Model Pembelajaran Concept Attainment Terhadap Kemampuan Komuniksi dan Pemahaman Konsep Siswa PAda Materi Sistem Reproduksi. 9(2), 1-5. 